\title{
Ethical Leadership, Corruption and Irresponsible Governance: Rethinking the African Dilemma
}

\author{
Godwyns Ade' Agbude \\ Lecturer, College of Development Studies \\ Department of Political Science and International Relations \\ Covenant University, Ota, Ogun State, Nigeria \\ agodwins@yahoo.com, +234-08034854242

\section{Paebi Ibenadou Etete} \\ Graduate of Political Science \\ Department of Political Science and international Relations \\ Covenant University, Ota, Ogun State, Nigeria \\ paebietete@ymail.com, +234-08064827917
}

Doi:10.5901/mjss.2013.v4n6p481

\begin{abstract}
In the face of current events in the global community, Africa cannot afford to lag-behind in pursuing a meaningful sustainable development in all strata. The current crisis of relevance of the African societies in the comity of nations is traceable to the obvious poverty, under development, irresponsive and irresponsible governance, illegitimate political administrations, prolonged military administrations, martial social and economic systems, repressive policies, and etc. This paper employed qualitative method of research dwelling on the use of secondary data, analyzed through the method of content and descriptive analysis. From the secondary data gathered and analyzed, it was discovered that the dilemma of the African societies is the absence of public spirited leadership which these writers preferred to refer to as Ethical Political Leadership. A society either rises or falls depending on the kind of leadership within its system. This paper therefore concluded that Africa needs this style of leadership that is first and foremost people-oriented. The absence of this has been the bane of any meaningful development in Africa. If we must develop and transverse this level of living at the mercy of the international organizations and almost absolute reliance on development assistance, African political leaders must rise to the responsibility of engendering a social system that will reduce corruption in both public and private spheres, and must also get involved in outright formulation and implementation of policies that will enhance the self-realization of the African citizens. Above all, this paper recommends the need for moral education in Africa.
\end{abstract}

Keywords: Sustainable development, Corruption, Leadership, Irresponsive governance and Moral Education

\section{Introduction}

The variables in our discourse are so important given the interrelated of them. Leadership is central in all human interactions and endeavours. Several definitions can be given for leadership. Hodgetts and Altman (1971: 182) define leadership as "the process of influencing people to direct their efforts towards the achievement of some particular goals". Goal setting is important to leadership activities. It is the job of a leader to direct the activities of all other people (the followers) towards an organizational goal. In the same vein, Newstrom and Bittel (2002) see leadership as the process of influencing and supporting others to follow and to do willingly the things that need to be done. While some leaders are constructive in the operations, others are destructive. A leader is expected to set constructive goals and galvanize the people to pursue the same. The other two variables - corruption and irresponsive governance are dependent on the kind of leaders are govern the State.

\section{Research Methods}

This research is carried out with the use of qualitative method with primary emphasis on the use of secondary data 
analyzed through content and descriptive methods of analysis. The sources of the secondary data include books, journals, articles among others.

\title{
3. The roots and dimensions of corruption in Africa
}

The whole Africa continent, at present, is engulfed in a search for sustainable development which is defined in the terms of:

i. A political system that secures effective citizen participation in decision making.

ii. An economic system that provides for solutions for the tensions arising from disharmonious development.

iii. An administrative system that is flexible and has the capacity for self- correction.

iv. A production system that respects the obligation to preserve the ecological base for development (Elliot, 1999: 8).

The imperative for development is the current drive among great nations in international politics. Nations who are at the fore front of leadership in world politics are those whose apparent holistic development is appealing to even the most unenlightened minds.

Africa has, over many decades, been tagged a developing continent. Some critics prefer to refer to Africa as an un-developed continent. According to these critics, Africa seems not to be making any meaningful progress in terms of development. Even though this writer raises a voice of dissent to this, we cannot but acknowledge the vivid attestation to slow progress (development) in Africa.

This issue of development has further created a bifurcation among nations of the world between what is known as Developed Nations and Undeveloped (Developing) Nations. In other words, there is a creation of the nomenclature called Third World Nations of which Africa continent is a chief.

Robert Mugabe, in his Daily Times Lecture (Jan. 1991) succinctly puts the African tragedies this way:

\begin{abstract}
Africa is now home to the world's largest number of least developed countries. The continent further boasts of the largest refugee population in the world. Furthermore, it is a theatre of endless conflicts, civil strife and gross human right abuses. Whereas standards of living in other continents have risen over time, in Africa, present standards of living are not better than they were two decades ago. High unemployment, inflation, civil strife, poverty, refugee crisis, desertification, disease, malnutrition- the list is endless-appear to be the only legacy the continent is capable of passing from one generation to the other (Mugabe, 1991: 22).
\end{abstract}

This political leader's description of the African tragedies 19 years ago is still a perfect description of the present postcolonial African states. The African postcolonial societies seem not to be committed to changing these perennial social eco-political afflictions plaguing and threating her importance in the comity of nations. The battle however is not the battle of relevance but that of solving her multifaceted social eco-political anomalies so that her citizens will emerge as proud men and women who have been treated well in life. Till present, we Africans belong to a continent whose inability to solve her own problems has kept her powerless in the face of other nations.

Other continent, especially the East Asian countries in the Asia continent, seem to be making meaningful progress and advancement in politics, economy, technology and etc, while Africa seems to be living up to her old nickname: The Dark Continent.

Though, Mugabe's contribution to the woes of his country, possibly, that of Africa is not in doubt. That notwithstanding, his description is a great picture of the postcolonial African states; and therefore, we should not feel sentimental to our usage of his description of the African tragedies in this discourse.

This study draws a clear cut analysis that shows that the major inhibition to development in Africa is basically corrupt practices in the corridor of power demonstrated in irresponsive governance.

Olusegun Obasanjo the former President of Nigeria has this to say at the beginning of his tenure in May 1999:

Corruption, the greatest single bane of our society today, will be tackled head-on at all levels. Corruption is incipient in all human Societies and in most human activities. But it must not be condoned. No society can achieve anything near its full potential if it allows corruption to become the full-blown cancer it has become in Nigeria. Nobody, no matter who and where, will be allowed to get away with breach of the law or the perpetration of corruption and evil (Obasanjo, 2005). 
This is an acknowledgement of the fact that corruption is prevalent in our society. This declaration in itself did not end corrupt practices as it was also prevalent in his tenure cumulating in the battle for the third term in office contrary to the constitution.

Scholars' interrogations of the Africa predicaments reveal that our embattled development is inhibited by lack of positive, ethical and public leadership which they claim has deterred the citizens' interest and trust in the state.

This study therefore draws a convergent point between leadership and corruption in Africa.

Agyeman, an African scholar, underscores this thus:

If we were to be very honest with ourselves, we surely would not find it too difficult to be convinced of the fact that Africans have been irresponsible and harmful to Africa in terms of self-governance (Agyeman, 2003: 276-291).

The idea of irresponsive governance is demonstrated in the leaders' impassive, indifferent and lethargic attitude towards the concept of citizenry as the real basis for governance. Our common experience in Africa has been that of Leadership who do not see the difference between the public funds and their private funds.

Chinua Achebe in his book The Trouble With Nigeria posits thus:

The trouble with Nigeria is simply and squarely a failure of leadership. There is nothing basically wrong with the Nigeria character. There is nothing wrong with the Nigeria land or climate or water or air or anything else. The Nigerian problem is the unwillingness or inability of its leaders to rise to the responsibility, to the challenge of personal example which are the hallmarks of true leadership. I am saying that Nigeria can change today if she discovers leaders who have the will, the ability and the vision (Achebe, 1983:1).

This was said about Nigeria, but by implication the whole Africa continent has this similar experience of inhumane leadership style.

This writer shares the same sentiment with Achebe that our quest for development and good governance in Africa rises and falls on the ideal kind of leader which I have referred to as Ethical Leadership.

It is the national ruling class itself that constitutes the principal obstacle to economic growth and development through the privatization of the state, depriving it of those essential means and capabilities with which to generate economic growth, improve the living conditions of the masses (Nzongola, 1984: 7-26).

As far as the present democratic governance in Africa is concern the people are treated, by most of the political leaders, as nothing but just mental phenomena (ideas in the mind) only relevant at the point of electoral processes. The kind of democracy practiced in most African States is nothing but electoral democracy (voting and being voted for). The implication of this is the incipient of an idealistic conception of politics in which the people are not treated as having an objective practical relevance; policies without human-face (non-socio centric policies) are formulated without recourse to the people. Thus, the state that should protect the people becomes a predator to the people.

The elite, like the colonial state, which they inherited has grown apart from the society. Increasingly the state and the elite who control the state, have become predators of the society (Ade Ajayi, 1999: 9-17).

For instance, the intrigue in Africa polities is such that the perpetual cry for liberation and independence by Africans is still deafening till date. The first cry for independence by Africans was from colonial masters. The second was from inhumane, unconstitutional, impassive and oppressive imperial military dictators which we earnestly pray not to witness again. The third ongoing cry for independence by Africans is from irresponsive, irresponsible, corrupt egoistic political leaders who have knowingly (or unknowingly) and willingly (or unwillingly) imposed corruption, poverty and undevelopment as necessary social incentives on their people.

What these produce is nothing but the Darwinian survival of the fittest and the elimination of the unfit. The society becoming a theatre of war where everyone has to survive on his/her own since the government, through the leaders, has refused to provide a viable social-political construct (platform) for fair and moral competitions, and citizens' realization of self projections and goals. We are, at present, grabbling with a situation of every man, in a bid to survive, taking advantage of others. A situation Thomas Hobbes, a great political theorist, describe as homo lupus homini-man becoming wolf to man.

This is the source of the several corrupt practices witnessed at every facet of our society in Africa. 
Dukor underscores the issue of corruption in Africa thus:

Corruption has endemic, cancerous, and oracular tendencies. It is endemic because it normally catches up with a people or community. It is cancerous because it spreads from one person to the other until it engulfs the whole society. It is oracular in nature because once it spreads in a system, people tend to believe in it just as people of ancient times believed in and worshipped oracles. In a corrupt society, people tend to think that no one can be successful without being corrupt. Secondly, corruption can easily be located among the powerful. It is the most privileged and powerful that can easily become corrupt and thirdly corruption is most of the time systematic and structural. It has to with the consciousness, belief, institutions and governments of the people.... Naturally, therefore, to attack corruption means to attack these factors collectively and individual (Dukor, 1990: 21).

The influence of corruption flows from the leaders to the citizens. Since the state lost its role as a protector or a provider of viable socio-eco-political constructs for the realizations of citizens' goals and projections, the people took to personal survival through the philosophy of the ends justifies the means.

This scholar's poignant statement is very instructive.

...the type of leadership prevalent in any society largely determines what that society eventually becomes....the political and economic strength of a nation, the moral and cultural direction the nation follows, the progress and respect it commands from other nations, are largely traceable to the type of political leadership available in that society (Agulanna, 2006: 255-264).

Obviously from the clarifications above, our present situation is not just the doing of corrupt citizens but rather the corrupt legacies of political leadership whose lack of respect for public interests and public funds has led to the deterioration in citizens' interest in the state.

\section{The Theoretical Basis}

With convergence theory ${ }^{1}$ (a social psychology theory-crowd psychology) which holds that crowd behavior is not a product of the crowd itself, but is carried into the crowd by particular individuals. We, therefore, intend to argue that corruption as a vice is transmitted from the individuals (leaders) to the crowd (the masses). Thus, we have a society whose value system has been eroded through corrupt practices at all levels both among the leaders and the led but generated first among the leaders.

For instance, money laundering is a common experience among our political leaders. How do we discourage and punish an average African from embezzling any money at his disposal when he reads, in the pages of Newspapers, of a lot of Governors of different States in his country who were accused and charged for money laundering and still go unpunished? It is the leaders that break most of the laws guiding the State.

Therefore, in the strength of the Convergent theory, this writer holds that corruption has only one prominent root in Africa; and that is leadership. At the base of corruption in every facet of our continent is the kind of leadership that is being provided. There are two reasons for this.

First, when the kinds of leaders that rule a nation do not show credible virtuous characters, they will produce followers who will not have regard for social sanity as well. When leaders are obsessed with crude accumulation of wealth, the followers' adventures into political positions will also be to take their part of the 'national cake'. The public funds become the basis for inhumane and cruel assassinations of political opponents in order to gain ascendancy to political positions and then make away with as much money as they can.

At present, in Africa, politics is a lucrative business such that becoming a politician is synonymous with becoming a sudden millionaire if not a billionaire. Thus, the whole society is engulfed with people who emerge as political leaders with the intention of ravaging the national treasury. In other word, the perennial recruitment of corrupt leaders becomes the daily experience of the African societies. Those who emerge as leaders have their eyes on the public funds as though politics is all about corrupt and fraudulent financial misappropriation.

Second, when the political leaders are impassive to the people, the people take to personal survival which could entail taking advantage of others. This will lead to what has been referred to as gorilla warfare in the society. This is our present experience in Africa. In a bid of self-survival, we engage in activities that are inhumane to our fellow men even in the business world.

Edo Utok, points out, succinctly, the importance of morality in Africa when he opines that: 
What is required for Africa to develop is more than the acquisition and application of scientific knowledge. Development has an ethical component which Africans could neglect at their own peril (Utok, 1998: 276-291).

To correct this social anomaly, we recommend ethical leadership as the only viable means of restoring sanctity in the Africa communities. This is because whatsoever a society becomes is a by-product of its leadership style given that the concept of 'Influence' is central to leadership. If Africa gets its leadership style right (ethical leadership) then ethical citizenship will naturally follow.

\title{
5. Understanding Ethical Leadership
}

The survival of our continent, the restoration of the hope of the people in governance, the total sanitation of our society from corrupt practices rests on the shoulders of the leaders. No leader can effectively correct this anomaly except that which is ethical.

\begin{abstract}
...ethical leadership takes into account not only the leader but also his constituents (followers and key stakeholders)...Leaders are first and foremost members of their own organizations and stakeholder groups. As such, their purpose, vision, and values are for the benefit of the entire organization and its key stakeholders...Ethical leaders embody the purpose, vision, and values of the organization and of the constituents, within an understanding of ethical ideals (Freeman \& Stewart, 2006).
\end{abstract}

In other words, an ethical leader works primarily for the interests of all his followers whom he considers as key stakeholders. The principle of 'the others' is paramount to ethical leadership.

This explains the reason for the failure of democracy in Africa. In other word, unethical leadership is the bane of effective democratization in Africa. Democracy is by nature about the people. But immoral leaders in Africa removed the people in the democratic enterprise and yet proclaim themselves as democrats.

When the concept of citizenry is lost in any polity what we will be left with will be nothing but irresponsible and irresponsive governance.

Robert Dahl argues:

I assume that a key characteristics of a democracy is the continuing responsiveness of the government to the preferences of its citizens, considered as political equals...I should like to reserve the term 'democracy' for a political system, one of the characteristics of which is the quality of being completely or almost responsive to all its citizens (Dahl, 1971).

The inhibition to democracy in Africa is obviously the operators of the democratic values-the political leaders. There is an undeniable presence of corruption at all levels in Africa because those in the helms of affair have not provided the kind of leadership that is necessary for the emerging of social-eco-political constructs that is corruption free in Africa.

\section{Corruption: A Conceptual Definition and Theoretical Underpinning}

Corruption has been at the centre of discourse among researches and academia.

Gould defined corruption as "an immoral and unethical phenomenon that contains a set of moral aberrations from moral standards of society, causing loss of respect for and confidence in duly constituted authority" (Gould, 1991: 761774). This definition underscores the fact that corruption involves devaluation of values and loss of rest for social, ecopolitical institutions and for those in place of authority. This definition is not too different from Dobel's conception of corruption as "the moral incapacity to make disinterested moral commitments to actions, symbols, and institutions which benefit the substantive common welfare" (Dobel, 1978: 958-973).

It is a uniform argument in the definitions above that corruption is a moral failure. To my mind, a moral failure can only be rectified through appropriate moral cautions in any political community.

A general moral failure in any society can only be successfully traced to those who hold the power of governance namely Executive, Legislature and Judiciary, in the case of democratic governance. Jain defined corruption as "an act in which the power of public office is used for personal gain in a manner that contravenes the rules of the game" (Jain, 2001: 71-121). This definition reveals that general corrupt practices cannot be explained in any society without reference 
to those in the position of power. Waterbury's definition of corruption as "the abuse of public power and influence for private ends" (Waterbury, 1973: 533-555) further shows that society's corruption has a link with political leadership. That corruption has a negative impact or influence on the economy of any society is not debatable. This explains the reason of the underdevelopment of the developing countries who are highly rated in the Corruption Index of Transparency International. Corruption has been the bane of the developing nations and this can only reversed through 'Ethical Political Leadership'.

There have been several theories that tried to capture the widespread of corruption in any society. These theories include the following: Idealist, Modernist, Marxist and Functionalist.

In Africa, the most appropriate theory that can be used to explain the widespread of corruption across all sectors in Africa is the Marxist theory of corruption. This theory holds that corruption is a consequence of the peripheral capitalist development (Akpotor, 2003: 355-367).

In other word, corruption can be explained as a by-product of the bourgeoisie (the ruling class/elites) exploitation of the socio-eco political situations in any country.

This implies that, in Africa, the ruling class, as outlined in the leadership crisis in Africa, has been the major root and cause of the complete percolation of corruption into the whole segment of the society. The ruling class, as Achebe posits, has not been able to rise to the responsibility and to the challenge of personal example which are the hallmarks of true leadership.

Therefore, if our leadership style changes; if the Marxist theory's claim that corruption emanates from the leaders and then spreads to the masses (which the convergent theory in social psychology cited above tried to explain) can be seriously addressed in Africa such that the leaders become ethical in their disposition to governance, then Africa shall be on a tour to minimizing (no continent or country can prove to be corruption free) corruption as a social vice.

At the point of governance, this writer believes that until we are able to generate moralist political culture in Africa, we cannot in any way minimize corruption in our society.

In support of the President of United States, Barack Obama's claim that Africa does not need strong leaders but rather needs strong institutions (Nnamani, 2010) that will help in curbing unethical, egoistic pursuit in the society; we posit that Africa needs ethical leaders that will help in building strong institutions. This is because the institutions have to be built by the leaders who themselves will not manipulate the laws and institutions they set up against trespassers. Leaders who have not and would not themselves trespassed against the institutions they set up. We have had strong leaders, now we need ethical leaders.

The search for successors by outgoing political leaders in Africa without giving cognizance to the consent of the electorates has always been because of avoidance of being probed by incoming leaders. Therefore, political leaders in Africa who may be strong but not ethical always want to cover up their immoral accumulations of the public funds by getting successors who will conceal their evils and possibly be loyal to them by giving them access for continuous looting or sharing of looted national treasury.

\section{The Defining Features of Ethical Leadership as the Model for Africa}

Ethical Leaders work to create an open, two-way conversation, thereby maintaining a charitable understanding of different views, values, and constituents' opinions. They are open to others' opinions and ideas because they know those ideas make the organization or country they are leading better (Freeman \& Stewart, 2006). In other word, there is a full integration of the people into the art of governance. This is against the politics of treating the electorates as mental phenomena only relevant at the point of electoral processes.

Ethical leaders see their leadership as a fully ethical task. This entails taking seriously the rights claims of others, considering the effects of one's actions on others (citizens), and understanding how acting or leading in a certain way will have effects on one's character and the character of others. The goal of ethical leadership entails the building of a moral community that is a necessity for viable development.

Ethical leadership requires an attitude of humility rather than righteousness: a commitment to one's own principles, and at the same time, openness to learning and to having conversations with others who may have a different way of seeing the world. 


\section{Conclusion}

This model of leadership that focuses on the people and the community (country) first is a necessary antidote in combating our present leadership style in Africa that has been described as egoistic, parasitic, prebendal, neopatrimonial, predatory, praetorian, squandermania, hedonistic materialism, hypertensive materialism etc.

Ethical leadership, which this paper proposes, focuses on national success rather than on personal achievement. It emphasizes leadership accountability to the people. Therefore, given its peculiarity, all Africans must try to enthrone it as the most appropriate leadership style in governance.

The central point in this discourse so far is that of ethical political leadership by example. These leaders' commitment to the welfare of the people they govern will definitely affect the peoples' commitment to their fellow citizens and to the State at large.

Then, we can be sure that the kind of development we desire, which cannot be achieved in a corrupt political community, will be the experience of the African continent.

\section{Recommendations}

There is a need for moral and political education in Africa in order to ensure the advent of sustainable development. Sustainable development can only be engendered by ethical political leadership. This idea of holistic moral education is a necessity given that leaders are made from the people. Education in Africa must concentrate on the emergence of leaders who are not just intellectuals but also people of sound moral rectitude. This was what differentiated Plato and Aristotle. While Plato was concerned with educating the political leaders (the guidance), Aristotle was committed to educating the children of the citizens. Aristotle, for instance, believes that the central goal of education is to produce citizens of good character. Our education should focus on the right formation of the virtuous character of the leaders and the led.

This scholar underscores the importance of morality in Nigeria as it were in Africa thus:

Given the prevalence of poverty, increased tensions, violent and related social disorder, Nigeria is in need of moral rearmament. Traditional African societies thrived on a system of collective values which was severely disorganized by colonialism and its attendant value system essentially defined by extreme individualism and cut-throat competition that are inherent parts of capitalism (Sogolo, 2004: 3).

Moral education can restore Africans back to the path of collective commitment to the needs of one another instead of this present immoral pursuit of personal gains as it is evidently obvious in our social system - moral education at all levels of human interaction. This will entail laying value on the dignity of the human person. It will also involve respect for communal existence. It will also incorporate the necessity of tolerance.

\section{Notes:}

We intend to use this as the corrective measure in Africa. The individual leaders can effectively change the state of corruption in Africa if they will themselves change. If we get the leadership right, everything else will fall in place.

\section{References}

Achebe, Chinua. (1983). The Trouble with Nigeria. Oxford: Heinemann.

Ade-Ajayi, J.F (1999). "Development is about People". Viewpoint: A Critical Review of Culture and Society. 1(1\&2): 9-17

Agulanna, C. (2006). "Democracy and the Crisis of leadership in Africa". The Journal of Social, Political and Economic Studies, 31(3): 255-264.

Agyeman, K. (2003). "The quest for Moral democracy", in J.O Oguejiofor (ed.) Philosophy, Democracy and Responsible Governance in Africa. pp. 333-352. London: Transaction Publishers.

Akpotor Sunny. (2003). "Corruption: the civil society and government" in M. Dukor (ed.) Philosophy and Politics: Discourse on Values, Politics and Power in Africa. pp.355-367. Lagos: Malthouse Press Ltd.

Dahl Robert. (1971). Polyarch: Paticipation and Opposition. New Haven: Yale University Press

Dobel, J.P. (1978). "The Corruption of a State". The American Political Science Review, 72(3), 958-973. 
Dukor, M, (1990). "Corruption and Social Action in Nigeria". Philosophy and Social Action. 16(3):21 July-Sept quoted in Dukor, M. 2003. "Social movements and political resistance in Nigeria: Problems of Agenda and Social Action" (pp. 164-185) in Dukor, M. (ed) 2003. Philosophy and Politics: Discourse on values, Politics and Power in Africa. Lagos: Malthouse Press Ltd.

Edo Utok (1998). "Ethical conditions of Development in Twenty-first Century African" in Olusegun Oladipo (ed) Remaking Africa: Challenges of the Twenty-first Century. , pp.276-291. Ibadan: Hope Publications.

Edward R. Freeman and Lisa Stewart. (2006). "Developing Ethical Leaders". (c) 2006, Business Roundtable Institute for Corporate Ethics. www.corporate-ethics.org

Elliot, J.A. (1999). An Introduction to Sustainable Development. New York: Routledge

Gould, D. (1991). "Administrative Corruption: Incidence, Causes and Remedial Strategies", in Ali Farazmand (ed.) Handbook of Comparative and Development Public Administration. pp. 761-774. New York: Marcel Dekker Inc.

Jain, A.K. (2001). "Corruption: A Review". Journal of Economic Surveys, 15(1): 71-121

Hodgets, R. M and Stevens, A. (1971) Organizational Behaviour. Philadelphia: V.B Saunders Company

Newstrom, J.W. and Bittel, L.R. (2007). Supervision Managing for Results, (8th ed.). New York: McGraw Hill

Nnamani, K. (2010) key note address delivered at The Sun Publishing Limited's “The Sun man of the year' aware ceremony at the Expo centre, Eko Hotels \& Suites, Victoria Island, Lagos, Saturday, February, 20,

Mugabe, R. (1991). "African in the New World Order: Europe 1992 and Beyond", a Daily Times (Nigeria) Special Lecture delivered on Jan. 9, 1991, but published in the same Newspaper on Jan. 10, 1991.

Nzongola-Ntalaja, J. (1984). "The Crisis in Zaire" in Africa's Crisis. London: Institute for African Alternative.

Obasanjo O. (2005). "Moving on: The significance of reform and change in Nigeria" delivered at the Economic and Financial Crimes Commission's first executive session, Abuja, 6 August 2005 quoted in Bureau of Public Service Reform 2007.

Sogolo, G. (2004). "Philosophy, Human Values and Social Order", A keynote Address presented at the 30th Anniversary Celebration of the Department of Philosophy at the University of Ibadan. Ibadan, 16th Sept

Waterbury, J. (1973). "Endemic and Planned Corruption in a Monarchical Regime". World Politics, 25(4): 533-555. 